\title{
PHYSICOCHEMICAL AND MICROBIOLOGICAL EXAMINATION OF RAW MILK
}

\author{
O. M. YAKUBCHAK, Doctor of Veterinary Sciences, Professor, \\ Department of Veterinary Hygiene named after Professor A. K. Skorokhodko \\ https://orcid.org/0000-0002-9390-6578
}

T. V. TARAN ${ }^{1}$, Candidate of Veterinary Sciences, Associated Professor, Department of Veterinary Hygiene named after Professor A. K. Skorokhodko https://orcid.org/0000-0002-9370-8539

V. O. USHKALOV, Doctor of Veterinary Sciences, Professor, Ukrainian Laboratory of Quality and Safety of Agricultural Products http://orcid.org/0000-0001-5694-632X

S. V. MIDYK, Candidate of Veterinary Sciences, Research Department for Monitoring the Safety of Agricultural Products, Ukrainian Laboratory of Quality and Safety of Agricultural Products http://orcid.org/0000-0002-2682-2884

K. O. BERLOUS, Undergraduate http://orcid.org/0000-0002-9846-0202

National University of Life and Environmental Sciences of Ukraine, 15 Heroyiv Oborony st., Kyiv 03041, Ukraine E-mail:olga.yakubchak@gmail.com; ttaran@ukr.net; ushkalov63@gmail.com; svit.mid@gmail.com

\begin{abstract}
Ukraine is actively implementing safety legislation and certain indicators of food quality, in particular, raw milk, to the requirements of the European Union. Modern requirements for raw milk require careful analysis of hygienic indicators. Raw milk materials supplied to "Bila Tserkva Dairy Plant" LLC and dairy plant in PJSC "Vita" of Kyiv Region were studied. The count of mesophilic aerobic and facultative anaerobic microorganisms (MAFAM) and the species composition of milk microflora, in particular, bacteria of the genus Salmonella, Staphylococcus aureus, Listeria monocytogenes, bacteria of Escherichia coli group, psychrotrophic and spore-forming microorganisms were determined by microbiological methods. Physicochemical methods were used to determine: density, mass fraction of dry matter, somatic cell content, acidity, purity group, mass fractions of protein and fat. According to research results, the quality of farm milk is in an order of magnitude better than milk obtained from private households, in particular, by MAFAM count. The technology of obtaining farm milk ensures its production of extra and first grades, while milk obtained in the conditions of private households - the first grade and non-grade. According to physicochemical parameters, milk obtained under different conditions did not differ significantly. Microbiological parameters differed significantly. The average count of MAFAM in the milk from
\end{abstract}


private households was $4361.25 \pm 241.15$, which is 12.6 times higher than MAFAM count even in milk of the first grade produced by a dairy farm. Irrespective of the season and conditions of raw milk production, all tested samples met the requirements of the current DSTU for the absence of bacteria of the genus Salmonella in $25 \mathrm{~cm}^{3}$, Staphylococcus aureus in $0.1 \mathrm{~cm}^{3}$, and Listeria monocytogenes in $25 \mathrm{~cm}^{3}$. Bacteria of the Escherichia coli group were not detected in farm milk during the year, in contrast to milk from private households, where they were detected in spring and autumn (20\% of cases). Both in farm and milk from private households, a group of mesophilic microorganisms prevailed over spore-forming and psychrotrophic ones. However, their number was different. Prospects for further research are to determine the sources of entering various types of microorganisms in raw milk and to develop procedures to eliminate the possibility of milk contamination with foreign microflora.

Keywords: raw milk, farm milk, milk from private households, milk microflora, quality parameters

\section{Introduction}

Ukraine is currently undergoing the necessary reforms to approximate regulations on food safety and quality, in particular milk and dairy products, in accordance with the Association Agreement with the European Union. Ensuring the proper quality and safety of raw milk and dairy products is especially important for the domestic consumer, as well as for the further promotion of Ukrainian food products to the European Union market $\left({ }^{1}\right.$ Kondrasii et al., 2016; Ministry of Agrarian Policy and Food, 2019). Of course, a rational and logical way to ensure the safety and quality of raw milk, and in the future - dairy products is to prevent their contamination by foreign substances and microorganisms on farms (CAC/RCP 57, 2004).

It should be noted that microorganisms that enter the milk differ in type, multiplication activity, and metabolism and are a factor that limits milk shelf life (Oliveira et al., 2011; Bohnlein et al., 2021). This phenomenon in the dairy industry also limits the export of dairy products (Chaharovskyi, 2020; Ukrinform, 2020).

\section{Analysis of recent researches and publications}

In 2018, a new national standard DSTU 2662:2018 "Raw cow's milk. Technical conditions" was developed, it was enacted on September 1, 2019 (2018). However, currently, it is almost impossible to meet the requirements of the standard for microbiological parameters, especially on farms that use outdated raw milk production technologies and do not always comply with modern hygiene requirements and private farms, and the share of such raw milk is significant for some facilities (Pronko et al., 2020). The new standard aims to increase milk quality requirements and regulate the use of low-grade milk for certain purposes, namely, for the production of non-food products, such as animal feed or technical casein (Ministry of Agrarian Policy and Food, 2019). However, such products can be produced by a very small share of market operators, and therefore often raw milk that does not meet the requirements is processed into dairy products, which increases the risk not only of defects but also diseases in consumers. Requirements 
of current regulations apply to operators only and are not related to individuals who produce milk for their consumption. As a result, according to the current requirements, producers must introduce good practices in the production, processing, and marketing of milk and dairy products ( ${ }^{2}$ Kondrasii et al., 2016; Ministry of Agrarian Policy and Food, 2019).

It should be noted that the count of mesophilic aerobic and facultative anaerobic microorganisms (MAFAM) in milk is one of the most important indicators not only of its quality but also safety. This indicator also determines the sanitary conditions for obtaining and primary processing raw milk, suitability for the manufacture of dairy products. The number of MAFAM in milk is considered the most critical indicator due to the fact that, in Ukraine, a significant share of raw milk for the dairy industry is milk obtained from farms that do not have proper hygiene and production practices (GHP/GMP) and private farms (Ministry of Agrarian Policy and Food, 2019; Pronko et al., 2020).

However, its cooling is mostly insufficient and occurs prematurely (Pronko et al., 2021). Such milk no longer has bactericidal properties during delivery to milk processing facilities and, in addition, with increasing temperature during transportation to the milk processing facilities, the microflora begins to multiply actively. The development of microflora in milk causes several changes that complicate technological processes and worsen the quality of dairy products. The influence of this factor depends on the season and ambient temperature (Bohnlein et al., 2021).

According to various authors, the maximum number of anaerobic spores is found in milk in late winter and spring, which may be due to reduced feed qual- ity and poor sanitation on farms during this period. The maximum number of heat-resistant bacteria was found in the summer months. In the autumn, their number decreased by two or more times (Burke et al., 2021).

The presence of heat-resistant bacteria in raw milk indicates that the milk is not cooled or cooled insufficiently immediately after milking because only psychrotrophic microorganisms, most of which have low heat resistance and inactivate at low temperatures, can develop in milk cooled to a temperature of $3-5{ }^{\circ} \mathrm{C}$. A large number of heat-resistant bacteria in milk can also arise due to violation in hygienic conditions of its production, as a result of which microorganisms from equipment, dairy utensils, etc. enter it (Ledo et al., 2020).

In the process of obtaining raw milk with proper quality, attention should be paid to water hygiene. The quality of water on the farm (for washing udder, washing and disinfecting milking equipment) must meet the requirements of the current standard for drinking water. High microbial contamination of water occurred when from 438 to 589 thousand psychrotrophic microorganisms were found in $1 \mathrm{~cm}^{3}$ of the experimental sample (Ledo et al., 2020).

In the presence of inflammatory processes in the udder, the number of microflora increases significantly, in particular, during the latent form of mastitis - up to tens of thousands, and in the case of clinical course - millions of bacteria in $1 \mathrm{~cm}^{3}$ of milk. Failure to comply with sanitary and hygienic requirements for milk production, animal diseases, especially subclinical mastitis, lead not only to a decrease in the nutritional value of milk but also to the fact that it becomes dangerous for human health (Moradi et al., 2021; Rios-Muniz et al., 2019). 
Thus, the safety and quality of raw milk are closely associated with the organization of hygiene requirements and compliance with sanitary measures on the dairy farm during its obtaining, primary processing, cooling, storage, and transportation to milk processing facilities. ( ${ }^{1}$ Kondrasii et al., 2016; ${ }^{2}$ Kondrasii et al., 2016; Jans et al., 2016; Willis et al., 2018; Zulauf et al., 2018).

The purpose of the work was to analyze the physicochemical and microbiological parameters of raw milk supplied to milk processing facilities.

\section{Materials and methods of research}

The work was performed in the period from December 2019 to November 2020. Samples of raw milk for laboratory tests were taken at "Bila Tserkva Dairy Plant" LLC and the dairy plant of PJSC "Vita" (Kyiv region) during its reception at the appropriate facilities.

The study of changes in the species composition of the microflora in all raw milk, which was received by the milk processing facilities, was performed depending on the season and the conditions of its production.

Determination of subclinical mastitis and organoleptic evaluation were performed at the sampling site. Physicochemical and bacteriological analyses were conducted in the Ukrainian Laboratory of Quality and Safety of Agricultural Products.

A sampling of milk was performed according to DSTU 8553:2015 "Raw milk and raw cream. Rules for acceptance, sampling and preparing samples for control" (2015).

The milk microflora concerning the contamination with microorganisms of different groups was studied using the following methods: the total count of bacteria was determined according to DSTU 7357:2013 "Milk and dairy products. Methods of microbiological control", the number of psychrotrophic microorganisms, cultures and colony counts were determined similarly but incubated in a thermostat at a temperature of $7.0 \pm 1.0^{\circ} \mathrm{C}$ for $7-10$ days. Detected microorganisms were identified using the "Bergey's manual of systematic bacteriology" (2007); spore-forming bacteria were determined by seeding the 4th, $5^{\text {th }}$, and 6th of six ten-fold dilutions of milk heated to $85^{\circ} \mathrm{C}$ for 10 minutes. Pasteurized milk of selected dilutions was added to Petri dishes, filled with IPA and kept in a thermostat at a temperature of $30{ }^{\circ} \mathrm{C}$ for 3 days, after which the number of microorganism colonies was counted; detection of Listeria monocytogenes was performed according to DSTU ISO 11290-2:2000 "Microbiology of food and animal feed - horizontal method of detection of Listeria monocytogenes"; detection of bacteria of the genus Salmonella was performed according to DSTU IDF 93A:2003 "Milk and dairy products. Determination of Salmonella” (IDF 93A:1985, IDT).

The number of somatic cells was determined according to GOST 2345390 "Milk. Methods for determining the number of somatic cells", milk density - according to DSTU 6082:2009 "Milk and dairy products. Methods for determining the density", acidity - according to GOST 3624-92 "Milk and dairy products. Titrometric methods for determining acidity", fat content - according to DSTU ISO 1211:2002 "Milk. Gravimetric method for determining the fat content (control method)" (ISO 1211:1999, IDT), protein content - by the method of formal titration GOST 25179-90 "Milk. Meth- 
ods for protein determination"; dry matter content - according to DSTU ISO 6731:2007 "Milk, cream and condensed milk". Determination of total dry matter content (control method) according to ISO 6731:1989, IDT.

The obtained research results were processed statistically using MS Excel. We calculated the mean values $(\mathrm{M})$, the error of the mean values $(m)$. The difference was considered probable for $\mathrm{P}<0.05$.

\section{Results of the research and their discussion}

We conducted an analysis of microbiological and physicochemical parameters of milk supplied to milk processing facilities from December 2019 to November 2020. In this case, we considered the origin of the milk (milk obtained under conditions of farms or from cows in private households) and the season.

During the study period, "Bila Tserkva Dairy Plant" LLC received $30 \%$ of premium milk and $70 \%$ of the first grade, however, according to some indicators, the milk also corresponded to extra grade. But the dairy plant did not exhibit extra milk, because the hygienic indicators (the content of somatic cells and microorganisms) did not correspond to this.

The research results of microbiological and physicochemical parameters of milk received for processing in "Bila Tserkva Dairy Plant" LLC are given in Table 1.

According to Table 1, fluctuations in performance depending on the season are noted. In terms of density, milk corresponded in most cases to extra grade in summer and autumn, as evidenced by the average density of milk received for processing from dairy farms in these seasons. In winter and autumn, the milk density corresponded to extra and first grades. Similar results were for the dry matter content. As for the number of somatic cells, milk corresponded to extra and higher grades only in summer, while in other times of the year, corresponded to the first grade. Moreover, the lowest number of somatic cells was in summer, the highest - in spring and winter due to the increase in the number of cows with mastitis in the cold season. The average number of somatic cells was $421.70 \pm 15.26$, which met the requirements for the first grade.

Milk acidity complied with current regulations during the year but was lowest in winter. The protein content was the highest in summer and autumn and slightly higher than the baseline (baseline $-3 \%$ ), lower - in winter and spring but within the current requirements for raw milk. The average was $3.27 \%$ during the year. The fat content in milk obtained from farms was the lowest in spring, and it was stable and slightly exceeded the baseline (baseline for Ukraine $-3.4 \%$ ) in other seasons. The average fat content, in this case, was $3.6 \%$. According to the purity group, the milk obtained from farms complied with the current DSTU 3662:2018 and was the first group throughout the year.

The data given in Table 1 shows that in farm and chilled milk in winter and spring the average MAFAM count was $<100$ thousand $\mathrm{CFU} / \mathrm{cm}^{3}$, which corresponds to the extra grade, but the number of somatic cells corresponded to the first grade in these seasons. In summer, this figure was more than 2 times higher and according to DSTU 3662:2018 corresponded to the extra grade. The average value of MAFAM count was $132.43 \pm$ 2.7. Thus, we note the influence of the season on physicochemical parameters and MAFAM count in raw milk obtained from farms. Taking into account all indicators used to determine the grade, high-grade milk was delivered to the 


\section{Physicochemical and microbiological parameter of farm milk depending on the season ("Bila Tserkva Dairy Plant" LLC) $(M \pm m, n=20)$}

\begin{tabular}{|l|c|c|c|c|}
\hline \multirow{2}{*}{\multicolumn{1}{|c|}{ Parameter }} & \multicolumn{4}{|c|}{ Season } \\
\cline { 2 - 5 } & $\begin{array}{c}\text { winter } \\
(03 / 12 / 2019- \\
28 / 02 / 2020)\end{array}$ & $\begin{array}{c}\text { Spring } \\
(02 / 03 / 2020- \\
29 / 05 / 2020)\end{array}$ & $\begin{array}{c}\text { summer } \\
(01 / 06 / 2020- \\
31 / 08 / 2020)\end{array}$ & $\begin{array}{c}\text { autumn } \\
(01 / 09 / 2020- \\
19 / 11 / 2020)\end{array}$ \\
\hline $\begin{array}{l}\text { Density, } \\
\mathrm{kg} / \mathrm{m}^{3}\end{array}$ & $27.99 \pm 0.15$ & $27.91 \pm 0.19$ & $28.18 \pm 0.09$ & $28.08 \pm 0.22$ \\
\hline $\begin{array}{l}\text { Mass fraction of dry } \\
\text { matter, \% }\end{array}$ & $11.99 \pm 0.03$ & $11.89 \pm 0.01$ & $12.36 \pm 0.01$ & $12.39 \pm 0.02$ \\
\hline $\begin{array}{l}\text { Purity group, not } \\
\text { lower than }\end{array}$ & $\mathrm{I}$ & $\mathrm{I}$ & $\mathrm{I}$ & $\mathrm{I}$ \\
\hline Acidity, ${ }^{\circ} \mathrm{T}$ & $16.22 \pm 0.09$ & $16.51 \pm 0.04$ & $17.09 \pm 0.05$ & $16.46 \pm 0.03$ \\
\hline $\begin{array}{l}\text { Mass fraction of } \\
\text { protein, \% }\end{array}$ & $3.28 \pm 0.02$ & $3.19 \pm 0.01$ & $3.29 \pm 0.02$ & $3.31 \pm 0.02$ \\
\hline $\begin{array}{l}\text { Mass fraction of } \\
\text { fat, \% }\end{array}$ & $3.61 \pm 0.03$ & $3.58 \pm 0.02$ & $3.63 \pm 0.01$ & $3.64 \pm 0.02$ \\
\hline $\begin{array}{l}\text { Number of somatic } \\
\text { cells, thousand } / \mathrm{cm}^{3}\end{array}$ & $436.22 \pm 25.01$ & $441.23 \pm 26.02$ & $381.21 \pm 3.01$ & $428.12 \pm 7.01$ \\
\hline $\begin{array}{l}\text { MAFAM count, } \\
\text { thousand CFU/cm }\end{array}$ & $96.21 \pm 2.06$ & $99.22 \pm 4.7$ & $231.27 \pm 1.23$ & $103.03 \pm 2.68$ \\
\hline
\end{tabular}

milk processing facility only in summer and partially in autumn, while in spring and winter milk corresponded to the first grade, in particular, due to increased somatic cell content and low density.

In PJSC "Vita", raw milk comes from farms $(41 \%)$ and private households $(59 \%)$. During the period under study, raw milk was of the first grade and non-grade. Quality parameters in milk obtained by PJSC "Vita" are given in Table 2.

Analysis of the data given in Table 2 , with regard to physicochemical parameters of raw milk received by PJSC "Vita" from private households, it should be noted that in some respects it differed significantly from milk received from farms. In particular, this applies to sanitary and hygienic indicators - the number of somatic cells and MAFAM count.

Milk from private households contained the least somatic cells in summer, as well as milk obtained from the farm, but the number of somatic cells in the first case was on average $278.25 \pm 17.84$, which met the requirements for extra and higher grades. However, if we compare the average values of the number of somatic cells in milk obtained from farms and private households, their number was 1.8 times higher in milk from farms. According to this indicator, milk from farms in winter and autumn was low-grade, and only in summer, it corresponded to the first grade.

According to MAFAM count, all milk received by PJSC "Vita" was accepted only in the second grade. Although according to the current regulations, nongrade milk for dairies was to be accepted only for technical purposes from January 1, 2020. The highest MAFAM count in milk from private households was in summer, as well as milk from farms, but this figure was 11 times higher in milk obtained from private households. Similar excesses were observed in other seasons, probably due to poor quality and insufficiently rapid cooling of milk in the private households. The average MAFAM count in milk from private households was at the level of 4358.61 \pm 286.15 , which is 4.9 times higher than 
MAFAM count in milk obtained on the farm $(892.10 \pm 75.58)$.

Farm milk in terms of density in some seasons corresponded to the extra grade, and from private households, the density index ranged from $27.51 \pm 0.01$ to 27.81 $\pm 0.20 \mathrm{~kg} / \mathrm{m}^{3}$, which corresponds to extra and first grades. Dependencies on the seasons were not noted. In terms of dry matter, milk from farms and private households did not differ much.

In terms of acidity, raw milk supplied to PJSC "Vita" met the norma- tive values $\left(16-18{ }^{\circ} \mathrm{T}\right)$ and averaged $17.27^{\circ} \mathrm{T}$. Milk from farms had an average acidity of $16.57^{\circ} \mathrm{T}$, which is $0.7^{\circ} \mathrm{T}$ higher because milk obtained from private households is not always able to cool quickly and efficiently immediately after milking.

The average protein content in milk from private households was $2.97 \%$ and thus was slightly lower than the baseline $(3 \%)$, except for milk obtained in autumn. In farm milk, this figure was on average at baseline. During the calendar

2. Microbiological and physicochemical parameters of milk received for processing by PJSC "Vita" from farms and private households $(\mathbf{M} \pm \mathbf{m}, \mathbf{n}=\mathbf{2 0})$

\begin{tabular}{|c|c|c|c|c|}
\hline \multirow[b]{2}{*}{ Parameter } & \multicolumn{4}{|c|}{ Season } \\
\hline & $\begin{array}{c}\text { winter } \\
(03 / 12 / 2019- \\
28 / 02 / 2020)\end{array}$ & $\begin{array}{c}\text { spring } \\
(02 / 03 / 2020- \\
29 / 05 / 2020)\end{array}$ & $\begin{array}{c}\text { summer } \\
(01 / 06 / 2020- \\
01 / 08 / 2020) \\
\end{array}$ & $\begin{array}{c}\text { autumn } \\
(01 / 09 / 2020- \\
19 / 11 / 2020)\end{array}$ \\
\hline \multicolumn{5}{|c|}{ Chilled milk from farms } \\
\hline Density, $\mathrm{kg} / \mathrm{m}^{3}$ & $27.5 \pm 0.34$ & $27.30 \pm 0.26$ & $28.03 \pm 0.36$ & $28.04 \pm 0.24$ \\
\hline $\begin{array}{l}\text { Mass fraction of dry } \\
\text { matter, \% }\end{array}$ & $11.51 \pm 0.16$ & $11.57 \pm 0.08$ & $11.74 \pm 0.12$ & $11.69 \pm 0.05$ \\
\hline $\begin{array}{l}\text { Purity group, not lower } \\
\text { than }\end{array}$ & I & I & I & I \\
\hline Acidity, ${ }^{\circ} \mathrm{T}$ & $16.88 \pm 1.25$ & $17.01 \pm 1.14$ & $18.03 \pm 1.16$ & $17.22 \pm 1.24$ \\
\hline $\begin{array}{l}\text { Mass fraction of } \\
\text { protein, } \%\end{array}$ & $3.03 \pm 0.01$ & $2.99 \pm 0.03$ & $3.01 \pm 0.04$ & $3.06 \pm 0.01$ \\
\hline Mass fraction of fat, $\%$ & $3.47 \pm 0.11$ & $3.38 \pm 0.02$ & $3.48 \pm 0.13$ & $3.62 \pm 0.04$ \\
\hline $\begin{array}{l}\text { Number of somatic } \\
\text { cells, thousand } / \mathrm{cm}^{3}\end{array}$ & $\begin{array}{c}629.14 \pm \\
23.01\end{array}$ & $\begin{array}{c}480.70 \pm \\
34.42\end{array}$ & $\begin{array}{c}398.04 \pm \\
45.01\end{array}$ & $\begin{array}{c}496.53 \pm \\
26.43\end{array}$ \\
\hline $\begin{array}{l}\text { MAFAM count, } \\
\text { thousand CFU } / \mathrm{cm}^{3}\end{array}$ & $\begin{array}{c}933.42 \pm \\
89.97 \\
\end{array}$ & $\begin{array}{c}1239.18 \pm \\
69.83\end{array}$ & $\begin{array}{c}1291.27 \pm \\
65.01\end{array}$ & $\begin{array}{c}1382.88 \pm \\
74,00\end{array}$ \\
\hline \multicolumn{5}{|c|}{ Chilled milk from private households } \\
\hline Density, $\mathrm{kg} / \mathrm{m}^{3}$ & $27.69 \pm 0.05$ & $27.81 \pm 0,20$ & $27.52 \pm 0.06$ & $27.51 \pm 0.01$ \\
\hline $\begin{array}{l}\text { Mass fraction of dry } \\
\text { matter, \% }\end{array}$ & $11.69 \pm 0.04$ & $11.52 \pm 0.05$ & $11.99 \pm 0.12$ & $11.57 \pm 0.03$ \\
\hline $\begin{array}{l}\text { Purity group, not lower } \\
\text { than }\end{array}$ & I & I & I & I \\
\hline Acidity, ${ }^{\circ} \mathrm{T}$ & $17.07 \pm 0.06$ & $17.27 \pm 0.14$ & $17.89 \pm 0.07$ & $17.33 \pm 0.29$ \\
\hline $\begin{array}{l}\text { Mass fraction of } \\
\text { protein, } \%\end{array}$ & $2.98 \pm 0.01$ & $2.89 \pm 0.07$ & $2.99 \pm 0.03$ & $3.02 \pm 0.04$ \\
\hline Mass fraction of fat, $\%$ & $3.49 \pm 0.09$ & $3.48 \pm 0.04$ & $3.45 \pm 0.2$ & $3.58 \pm 0.03$ \\
\hline $\begin{array}{l}\text { Number of somatic } \\
\text { cells, thousand } / \mathrm{cm}^{3}\end{array}$ & $\begin{array}{c}297.16 \pm \\
21.64 \\
\end{array}$ & $\begin{array}{c}271.16 \pm \\
18.25 \\
\end{array}$ & $\begin{array}{c}266.36 \pm \\
13.24 \\
\end{array}$ & $\begin{array}{c}279.75 \pm \\
18.23 \\
\end{array}$ \\
\hline $\begin{array}{l}\text { MAFAM count, } \\
\text { thousand CFU } / \mathrm{cm}^{3}\end{array}$ & $\begin{array}{c}1412.58 \pm \\
219.03\end{array}$ & $\begin{array}{c}1427.92 \pm \\
217.43\end{array}$ & $\begin{array}{c}14579.58 \pm \\
316.09\end{array}$ & $\begin{array}{l}1437.54 \pm \\
212.05\end{array}$ \\
\hline
\end{tabular}


year, the protein content in all samples of raw milk from farms and private households corresponded to the norm (not less than 2.8\%).

The fat content in milk obtained in private households was on average $3.5 \%$, which was $0.1 \%$ higher than the basic fat content and $0.1 \%$ lower than that in farm milk, so there is no reliable difference. Regarding the fat content in milk, depending on the season, this figure was the lowest in summer and the highest in autumn, which coincides with the trend observed for farm milk.
In terms of purity, milk obtained from private households did not comply with the current DSTU 3662:2018, as during the year it was assigned to the second purity group, which does not meet the requirements of the current standard and can be accepted at the milk processing facilities only as non-grade for technical purposes.

In addition, we studied the species composition of the microflora in milk obtained from farms and private households, depending on the season (Table 3).

3. The species composition of microorganisms in milk $(M \pm m, n=20)$

\begin{tabular}{|c|c|c|c|c|}
\hline \multirow[b]{2}{*}{ Microorganism } & \multicolumn{4}{|c|}{ Season } \\
\hline & $\begin{array}{c}\text { winter } \\
(03 / 12 / 2019- \\
28 / 02 / 2020)\end{array}$ & $\begin{array}{c}\text { spring } \\
(02 / 03 / 2020- \\
29 / 05 / 2020)\end{array}$ & $\begin{array}{c}\text { summer } \\
(01 / 06 / 2020- \\
31 / 08 / 2020)\end{array}$ & $\begin{array}{c}\text { autumn } \\
(01 / 09 / 2020- \\
19 / 11 / 2020)\end{array}$ \\
\hline \multicolumn{5}{|c|}{ Chilled farm milk } \\
\hline $\begin{array}{l}\text { Bacteria of the genus } \\
\text { Salmonella, in } 25 \mathrm{~cm}^{3}\end{array}$ & - & - & - & - \\
\hline $\begin{array}{l}\text { Staphylococcus aureus, } \\
\text { in } 0.1 \mathrm{~cm}^{3}\end{array}$ & - & - & - & - \\
\hline $\begin{array}{l}\text { Listeria monocytogenes, } \\
\text { in } 25 \mathrm{~cm}^{3}\end{array}$ & - & - & - & - \\
\hline $\begin{array}{l}\text { Bacteria of Escherichia } \\
\text { coli group, number of } \\
\text { cases, } \%\end{array}$ & - & - & - & - \\
\hline $\begin{array}{l}\text { Spore-forming } \mathrm{m} / \mathrm{o} \text {, } \\
\text { thousand } / \mathrm{cm}^{3}\end{array}$ & $12.09 \pm 0.07$ & $16.01 \pm 0.04$ & $19.37 \pm 0.07$ & $11.02 \pm 0.03$ \\
\hline $\begin{array}{l}\text { Mesophilic m/o, } \\
\text { thousand } / \mathrm{cm}^{3}\end{array}$ & $60.11 \pm 0.06$ & $55.18 \pm 1.24$ & $173.58 \pm 1.09$ & $62.92 \pm 0.74$ \\
\hline $\begin{array}{l}\text { Psychrotrophic } \mathrm{m} / \mathrm{o} \text {, } \\
\text { thousand } / \mathrm{cm}^{3}\end{array}$ & $24.01 \pm 0.03$ & $28.03 \pm 0.07$ & $38.32 \pm 0.79$ & $29.09 \pm 0.12$ \\
\hline \multicolumn{5}{|c|}{ Milk from private households } \\
\hline $\begin{array}{l}\text { Bacteria of the genus } \\
\text { Salmonella, in } 25 \mathrm{~cm}^{3}\end{array}$ & - & - & - & - \\
\hline $\begin{array}{l}\text { Staphylococcus aureus, } \\
\text { in } 0.1 \mathrm{~cm}^{3}\end{array}$ & - & - & - & - \\
\hline $\begin{array}{l}\text { Listeria monocytogenes, } \\
\text { in } 25 \mathrm{~cm}^{3}\end{array}$ & - & - & - & - \\
\hline $\begin{array}{l}\text { Bacteria of Escherichia } \\
\text { coli group, number of } \\
\text { cases, } \%\end{array}$ & 0 & 20 & 0 & 20 \\
\hline $\begin{array}{l}\text { Spore-forming } \mathrm{m} / \mathrm{o} \text {, } \\
\text { thousand } / \mathrm{cm}^{3}\end{array}$ & $19.44 \pm 0.13$ & $16.12 \pm 0,03$ & $67.18 \pm 0.02$ & $33.78 \pm 0.02$ \\
\hline $\begin{array}{l}\text { Mesophilic m/o, } \\
\text { thousand } / \mathrm{cm}^{3}\end{array}$ & $317.97 \pm 1.01$ & $341.84 \pm 0.59$ & $449.60 \pm 1.26$ & $342.74 \pm 1.92$ \\
\hline $\begin{array}{l}\text { Psychrotrophic } \mathrm{m} / \mathrm{o} \text {, } \\
\text { thousand } / \mathrm{cm}^{3}\end{array}$ & $75.17 \pm 0.09$ & $69.96 \pm 0.74$ & $29.98 \pm 0.75$ & $61.02 \pm 0.03$ \\
\hline
\end{tabular}


The results of the study are given in Table 3, indicate that regardless of the season and conditions, all tested samples of raw milk met the requirements of the current DSTU for the absence of bacteria of the genus Salmonella in $25 \mathrm{~cm}^{3}$, Staphylococcus aureus in $0.1 \mathrm{~cm}^{3}$ and Listeria monocytogenes in $25 \mathrm{~cm}^{3}$.

Bacteria of Escherichia coli group were not detected in farm milk during the year, in contrast to milk from private households, where this group of bacteria was detected in spring and autumn (20\% of cases).

As for the other microflora, both in farm and in milk from private households, a group of mesophilic microorganisms prevailed over spore-forming and psychrotrophic ones. However, their number was different, because in general, the average MAFAM count was 3.31 times higher in milk obtained in the conditions of private households (Tables 1,2).

The number of spore-forming microorganisms in farm milk is 5.5 times lower in summer and 3 times lower in autumn than in milk obtained from private households. In other seasons of the year, the number of spore-forming microorganisms in milk produced by economic entities with different forms of ownership did not differ significantly.

As for the mesophilic microflora, milk contamination in all seasons of the year was higher in the milk of cows from private households, although the smallest difference between the indicators was in summer. In particular, in winter -5.3 , in spring -6.2 , in summer -2.6 , in autumn -5.4 times.

The number of psychrotrophic microorganisms in farm milk, compared to the milk of cows from private households, differed the most in winter and was 3 times lower. In spring and autumn, it was lower -2.5 and 2.1 times, respectively, and in summer it differed the least and was only 1.3 times lower.

This difference in total bacterial contamination and individual groups of microorganisms in farm milk and milk obtained from private households, apparently, can be explained by the fact that the latter technology involves mixing several small batches of milk in one container, and cow owners give milk as a rule once a day, thus milk from evening milking (cooled) and morning (warm) can be mixed that activates growth and multiplication of microflora. In addition, the sanitary and hygienic conditions for obtaining, primary processing of milk from private households, its storage, and transportation do not meet modern requirements for the production and circulation of raw milk.

\section{Conclusions and future perspectives}

Quality parameters of raw milk depend on the conditions of its production and the season. Milk of extra and first grades comes from farms, and private households - only non-grade. In addition, in summer and autumn more premium milk is received. Problematic indicators that do not allow to obtain milk of extra grade in farm conditions are hygienic: MAFAM count and the number of somatic cells.

Raw milk obtained in the conditions of private households does not meet the requirements of the current DSTU 3662:2018 in terms of purity and MAFAM count, so now it remains relevant to cooperate with the owners and their use of appropriate milking and refrigeration equipment.

All tested samples of raw milk, regardless of the season and milk production conditions, met the requirements of the current standard for the absence 
of bacteria of the genus Salmonella in $25 \mathrm{~cm}^{3}$, Staphylococcus aureus in $0.1 \mathrm{~cm}^{3}$, and Listeria monocytogenes in $25 \mathrm{~cm}^{3}$.

Bacteria of Escherichia coli group were not detected in farm milk during the year, while in milk from private households they were recorded in spring and autumn ( $20 \%$ of cases).

In farm milk and milk from private households, a group of mesophilic microorganisms prevailed over spore-forming and psychrotrophic ones.

Prospects for further research are to determine the sources of entering various types of microorganisms in milk and to develop procedures to eliminate the possibility of milk contamination with foreign microflora, especially in private households.

\section{References}

Ministry of Agrarian Policy and Food. Vymohy do bezpechnosti ta yakosti moloka i molochnykh produktiv [Requirements for safety and quality of milk and dairy products]. № 118. (2019). Retrieved from https://zakon.rada.gov.ua/laws/show/z0593-19\#Text

Codex Alimentarius Commission. Code of Hygienic Practice for Milk and Milk Products. CAC/RCP 57-2004. Retrieved from http:// www.fao.org/fileadmin/user_upload/livestockgov/documents/CXP_057e.pdf

Bohnlein,C.,Fiedler,G.,Loop,J.,Franz,C.,\& Kabisch,J. (2021). Microbiological quality and safety of raw milk from direct sale in northern Germany. International Dairy Journal, 114, Article 104944. doi: 10.1016/j.idairyj.2020.104944

Oliveira, C. J. B., Hisrich, E. R., Moura, J. F. P., Givisiez, P. E. N., Costa, R. G., \& Gebreyes, W. A. (2011). On farm risk factors associated with goat milk quality in Northeast Brazil. Small Ruminant Research, 98(1-3), 64-69. doi: 10.1016/j.smallrumres.2011.03.020

Chaharovskyi, V. (2020). Molochna haluz Ukrainy ta yii maibutnie cherez 10 rokiv: problemy, natsionalna prohrama rozvyt- ku ta derzhavna pidtrymka [Ukraine's dairy industry and its future in 10 years: problems, national development program and state support]. AgroPolit.com. Retrieved from https://agropolit.com/blog/412-molochna-galuz-ukrayini-ta-yiyi-maybutnye-cherez-10-rokiv-problemi-natsionalna-programa-rozvitku-ta-derjavna- pidtrimka.

Ukrinform. (2020). Eksport molochnoi produktsii z Ukrainy tsohorich skorotyvsia na chvert [Exports of dairy products from Ukraine fell by a quarter this year]. Retrieved from https://www.ukrinform.ua/rubric-economy/3023697-eksport-molocnoi-produkcii-z-ukraini-cogoric-skorotivsa-na-cvert. html (in Ukrainian).

DSTU 3662:2018. (2018). Moloko-syrovyna koroviache. Tekhnichni umovy [DSTU 3662:2018 Raw cow's milk. Specifications]. Kyiv: DP "UkrNDNTs".

Pronko, L., Kolesnik, T., \& Samborska, O. (2020). Ukraine Dairy Market: State and Prospects of Development. European Journal of Sustainable Development, 9(1), 243-252. doi: 10.14207/ejsd.2020.v9n1p243

Burke, N., Zacharski, K., Adley, C. C., \& Southern, M. (2021). A comparison of analytical test methods in dairy processing. Food Control, 121, Article 107637. doi: 10.1016/j.foodcont.2020.107637

Campos, G. Z., Lacorte, G. A., Jurkiewicz, C., Hoffmann, C., Landgraf, M., Franco, B., \& Pinto, U. M. (2021). Microbiological characteristics of canastra cheese during manufacturing and ripening. Food Control, 121, Article 107598. doi: 10.1016/j.foodcont.2020.107598

Ledo, J., Hettinga, K. A., \& Luning, P. A. (2020). A customized assessment tool to differentiate safety and hygiene control practices in emerging dairy chains. Food Control, 111, Article 107072. doi: 10.1016/j.foodcont.2019.107072

Moradi, M., Omer, A. K., Razavi, R., Valipour, S., \& Guimaraes, J. T. (2021). The relationship between milk somatic cell count and cheese production, quality and safety: A review. International Dairy Journal, 113, Article 104884. doi: 10.1016/j.idairyj.2020.104884 
Rios-Muniz, D., Cerna-Cortes, J. F., Lopez-Saucedo, C., Angeles-Morales, E., Bobadilla-del Valle, M., Ponce-de Leon, A., \& Estrada-Garcia, T. (2019). Longitudinal analysis of the microbiological quality of raw cow's milk samples collected from three small family dairy farms in Mexico over a 2-year period. Journal of Food Protection, 82(12), 2194-2200. doi: 10.4315/0362-028x.jfp-19-155

Jans, C., Kaindi, D. W. M., \& Meile, L. (2016). Innovations in food preservation in pastoral zones. Revue Scientifique Et Technique-Office International Des Epizooties, 35(2), 597-610. doi: 10.20506/rst.35.2.2527

${ }^{1}$ Kondrasii, L. A., \& Yakubchak, O. M. (2016). Yakisni zminy moloka-syrovyny za vplyvu riznykh hihiienichnykh umov otrymannia [Raw milk changes qualitative under the influence of different hygienic conditions of production]. Naukovyi visnyk Lvivskoho natsionalnoho universytetu veterynarnoi medytsyny ta biotekhnolohii imeni S. Z. Gzhytskoho. 18(3(71)), 41-44.
${ }^{2}$ Kondrasii, L. A., Yakubchak, O. M., \& Osypova, T. Yu. (2016). Naukovo-praktychne obgruntuvannia pokaznykiv yakosti moloka-syrovyny za riznykh umov yoho vyrobnytstva [Scientific and practical substantiation of raw milk quality indicators under different conditions of its production]. Problemy zooinzhenerii ta veterynarnoi medytsyny. 33(2), 149-154.

Willis, C., Jorgensen, F., Aird, H., Elviss, N., Fox, A., Jenkins, C., Fenelon, D., Sadler-Reeves, L., \& McLauchlin, J. (2018). An assessment of the microbiological quality and safety of raw drinking milk on retail sale in England. Journal of Applied Microbiology, 124(2), 535-546. doi: 10.1111/jam.13660

Zulauf, M., Zweifel, C., \& Stephan, R. (2018). Microbiological quality of raw milk sold directly from farms to consumers in Switzerland. Journal of Food Safety and Food Quality-Archiv Fur Lebensmittelhygiene, 69(5), 140-144. doi: 10.2376/0003-925x$69-140$

\section{О. М. Якубчак, Т. В. Таран, В. О. Ушкалов, С. В. Мідик, К. О. Берлоус (2021). ФІЗИКО-ХІМІЧНІ ТА МІКРОБІОЛОГІЧНІ ДОСЛІДЖЕННЯ МОЛОКА-СИРОВИНИ. Ukrainian Journal of Veterinary Sciences, 12(2): 26-37, https://doi.org/10.31548/ ujvs2021.02.003}

Анотація. В Україні активно відбувається імплементація законодавства з безпечності та окремих показників якості харчових продуктів, зокрема, молока-сировини до вимог Європейського союзу. Сучасні вимоги до молока-сировини вимагають ретельного його аналізу за гігієнічними показниками. Досліджували сире молоко-сировину, що надходило на ТОВ «Білочерківський молочний комбінат» та молокозавод ПАО «Віта» Київської області. Мікробіологічними методом визначали кількість мезофільних аеробних та факультативно анаеробних мікроорганізмів (КМАФАМ) та видовий склад мікрофлори молока, зокрема, бактерії роду Salmonella, Staphylococcus aureus, Listeria monocytogenes, бактерії групи кишкових паличок, спороутворюючі та психротрофні мікроорганізми. Фізико-хімічними методами визначали: густину, масову частку сухих речовин, вміст соматичних клітин, кислотність, групу чистоти, масову частку білка та жиру. За результатами досліджень якість фрермерського молока є на порядок кращою, порівнюючи з молоком, отриманим в умовах особистих селянських господарств, зокрема, за КМАФАМ. Технологія отримання фермерського молока забезпечує його виробництво вищого й першого гатунків, у той час, як молоко, отримане в умовах особистих селянських господарств - першого гатунку та негатункове. за фрізико-хімічними показниками молоко, 
отримане за різних умов, достовірно не відрізнялося. Суттєво відрізнялися мікробіологічні показники. Середній показник КМАФАМ молока з особистих селянських господарств був 4361,25 241,15 , що у 12,6 раза перевищує КМАФАМ, навіть молока першого гатунку, отриманого в умовах молочнотоварної фрерми. Незалежно від пори року й умов отримання молока-сировини всі досліджені проби відповідали вимогам чинного ДСТУ щодо відсутності бактерій роду Salmonella у $25 \mathrm{~cm}^{3}$, Staphylococcus aureus, у 0,1 $\mathrm{cm}^{3}$ ma Listeria monocytogenes, у $25 \mathrm{~cm}^{3}$. У фермерському молоці не виявляли бактерій групи кишкових паличок упродовж року, на відміну від молока з особистих селянських господарств, де їх виявляли навесні і восени (по 20\% випадків). Як у фермерському, так і в молоці з особистих селянських господарств переважала група мезофільних мікроорганізмів над спороутворюючими і психротрофними. Проте їхя кількість була різною. Перспективи подальших досліджень полягають у визначенні джерел потрапляння різних видів мікроорганізмів у молоко-сировину та розробленні процедур усунення можливості обсіменіння молока сторонньою мікрофлорою.

Ключові слова: молоко-сировина, фермерське молоко, молоко з особистих селянських господарств, мікрофлора молока, показники якості 